\title{
E-Government Implementation in the Education Zone Service in Makassar City
}

\author{
Dety Yunita Sulanjari \\ Universitas Sawerigading Makassar \\ E-mail: detyyunita.sulanjari@gmail.com
}

\begin{abstract}
Implementation of e-Government in the service of Education Zones is one way to realize government services in the field of education and aims to equalize the quality of education. The purpose of this study is to find out how e-government implementation in the Education Zone service in Makassar City. This study uses a qualitative approach that is descriptive in nature. The subjects of the research were the Head of the Education Office, the headmaster of junior and senior high school students, parents. The results showed that the implementation of e-government in the service of education zones was not yet fully targeted because of the lack of standardization of the quality of teachers and infrastructure so that improvements and standardization in improving the quality of education were needed.
\end{abstract}

Keywords: Implementation; service; education; zoning system

\section{INTRODUCTION}

The implementation of e-Government is one way to realize better government services because in government a better service is needed that is transparent/open, both the information and ongoing activities within a government (Basu, 2004; Horsburgh, Goldfinch, \& Gauld, 2011; Silcock, 2001). Therefore, the application of e-Government in each area needs to be implemented in addition to improving the quality of people's lives. Information can be accessed 24 hours wherever and whenever the community does not need to come to the government office and openness is expected to change the relationship between the government and the community to be better. In addition, the application of e-Government requires human resources and infrastructure (Hardjaloka, 2014; Sosiawan, 2008).

Application of e-Government in education services through the implementation of the education zone in the Acceptance of New Students (PPDB) according to (Peraturan Menteri Pendidikan dan Kebudayaan No. 17 Tahun 2017, 2017). As for the purpose of the zoning system, the government wants to reform the school as a whole. The target of the government is to hold the equal distribution of the quality of education.

The zoning system is part of the school reform effort in improving the quality of education in Indonesia. The existence of this zoning system is able to create equality, high achieving students do not gather at favorite schools because they inevitably have to register at the nearest school and cannot register at a distance school even though they hold favorite status (Andina, 2017; Purwanti, Irawati, \& Adiwisastra, 2018; Wulandari, Hasyim, \& Nurmalisa, 2018).

The zoning system in PPDB is a policy for equalizing the quality of education which is expected to eliminate the term favorite school or superior school. Finally, the quality of each 


\section{Jurnal Administrare: Jurnal Pemikiran Ilmiah dan Pendidikan Administrasi Perkantoran Volume 6 Number 2 July- December 2019. Pages 153-158}

school can be seen because all this time favorite schools have always produced students who excel because New Student Admissions are trying to rigorous selection so that only highachieving students are accepted. With the zoning system, non-favorite schools also have the opportunity to show that they can be like superior schools in quality and quality because the BOS funds obtained are the same, so the good opportunities are the same, as quoted in (Pangaribun, 2018).

In addition, the existence of this zoning system will spur improvement in the quality of teaching staff and education because schools will accept students who excel so that inevitably the quality of teachers must be improved in order to foster good students (Mashudi, 2019; Rahmawati \& Muflhatin, 2019). So that there is no more accumulation of quality human resources in a particular area. This is expected to eliminate the education quality gap between cities and regions because of the same treatment, and students who have high academic potential will not think of going to school outside of zoning. Schools must accept prospective new students who live in the closest zone radius of the school at least 90 percent of the total number of students received. Domicile of prospective students is based on the address on the family card which is issued no later than within 6 months before the implementation of the acceptance of new students. The nearest zone radius is determined by the local government in accordance with the conditions of the area by taking into account the availability of school-age children in the area.

The zoning system is a new student admission system that is given by determining the zone radius by each local government and schools must accept prospective students who live in the closest zone radius with a certain percentage of the total number of students to be received (Farlina \& Ikhwani, 2017; Ningtyas, Badrul, \& Sulistyowati, 2018). The zoning system is a recommendation from the Ombudsman of the Republic of Indonesia in 2016 to the Ministry of Education and Culture, the Ministry of Home Affairs, and the Ministry of Religion and then implemented by the Minister of Education and Culture with the aim to eliminate the predicate of favorite and non-favorite schools. At present, the zoning system has been implemented nationally including in Makassar City since 2017. So this zoning system policy is important to study because the results can be a reference for other schools.

\section{METHOD}

This research uses a qualitative approach. This research was conducted at the Makassar City Education Agency with the address at Jl. Perintis Kemerdekaan of Makassar City. Data collection techniques using interviews, observation and documentation. This study uses a semistructured interview. Informants in this study include principals, teachers, students. This study uses passive participatory observation, the documents that are used as data sources in this study are the profile of the institution, documentation of the number of students who are either in zones or outside zoning, PPDB system mechanism.

\section{RESULT AND DISCUSSION}

Based on the results of the study it is explained that the implementation of e-Government through the Education Zone in Makassar using the concept of George Edwards III: 


\section{Communication}

The implementation of the zoning system in PPDB in Makassar is based on Permendikbud no. 14 of 2018 then revised to Permendikbud no. 51/2018 concerning acceptance of new students in the 2019/2020 school year. The Office of Education issues the PPDB Technical Guidelines which regulate the mechanism of GDP activities in full and detail related to general provisions, the list of PPDB zoning, the selection path to the PPDB implementation schedule. The implementation of PPDB activities has been carried out in accordance with the objectives in the PPDB Technical Guidelines. This can be seen in the list of PPDB Technical Guidelines. PPDB aims to provide opportunities for students from economically disadvantaged families as proof that PPDB aims to provide opportunities for students from economic families.

The implementation of the education zone policy is made to make a change or transformation that is to provide equal distribution of quality education in each district in the city of Makassar. Featured high schools in Makassar such as SMA 5, SMA 2, and SMA 12 are no longer available. The design of the policy is designed in such a way as to create a change in the environment and behavior of individuals or groups and have a positive and negative impact on society and on the implementers. Prior to the education zone policy, students were able to choose which school was considered free and superior in Makassar City even though the distance between the school and the residence was far without a quota limit, whereas after the zoning system was implemented the students could no longer be free to choose a school because of the opportunity students who register from outside the zone are limited to a quota of only $5 \%$.

\section{Owned Resources}

The quality of schools that have not been evenly judged makes it difficult for students to obtain proper education according to their capacity and presentation. Students are forced to enter schools in their residential zones. This has the potential to inhibit the interests and talents of students who have been nurtured well in previous schools.

In addition, the rules of the zoning system limit the space for students to get the best education services, the goal of the government is to optimize the quality of the presentation of educational services in terms of infrastructure and the quality of the instructors. The government is required to accelerate the improvement of the teaching quality of teaching staff. One of them is by reducing the administrative burden and encouraging the digitization of schools so that the teaching staff can focus on inspiring and educating students optimally.

\section{Dispotition or Behavior}

Based on observations and interviews with one of the parents' representatives who said that this zoning system provides a sense of comfort for parents that their children no longer need to go to school with a school radius that is quite far away. Parents can monitor student activities at school. 


\author{
156 Jurnal Administrare: Jurnal Pemikiran Ilmiah dan Pendidikan Administrasi Perkantoran \\ Volume 6 Number 2 July- December 2019. Pages 153-158
}

\title{
Interaction
}

Based on observations made by researchers, the zoning system of education still found several problems. As students, the distance between the house and the school, including close, is not accepted at the nearest school. Because it is already filled with those closest to the school. Based on the results of interviews with the school principal stating that the implementation of the zoning system will be followed up with the fulfillment of the number of schools, equitable distribution of infrastructure and infrastructure. And fulfillment, structuring and even distribution of teachers. The local government must first calculate the number of needs in the determination of zoning. The regional government also helped in the implementation of the education zoning system, both in terms of registering new students, and also helping to synergize teacher training in the regions to improve the quality of services and the quality of education.

\section{Discussion}

\section{Communicarion}

The zoning system policy is one of the policies of the New Student education regulated in Permendikbud Number 14 of 2018 and no. 51/2018. The implementation of the zoning system is intended to eliminate educational discrimination so that the quality of education is able to be generalized

The ongoing implementation of the education zone provides a clear change in Makassar City, control and top-down system and resources that can carry out the implementation tasks (Pressman \& Wildavsky, 1973). The opinion is also in accordance with (Grindle, 2010) which says that the policy is largely determined by the content (content) of the policy. Every policy has a target to be achieved. One of the successful implementation is very much determined by the implementers of the policy. Implementing the education zoning policy involves the Office of Education and schools that have components in their fields for the success of a policy.

\section{Owned Resources}

The available resources are in the form of teachers and school infrastructure. The application of the zoning system in the Acceptance of New Students (PPDB) is said to have a good aim at equalizing the quality of education. But there will be chaos if the policy is not accompanied by teacher standardization. With the zoning approach, it is necessary to improve various national education standards. Implementation will not be effective if the relationship of all agents who carry out the policy actually produces an "implementation deficit". Objectives must be clearly defined and well understood, resources must be provided, the chain of command must be able to unite and control these resources, and the system must be able to communicate effectively and control the individuals and organizations involved in carrying out the task. Implementation requires a top-down control and communication system and resources that can carry out these implementation tasks (Pressman \& Wildavsky, 1973) 


\section{Dispotition or Behavior}

The implementation of the education zone provides a change in behavior for policy implementers. With the good top-down communication can help the implementation of policies properly. Success in implementation is strongly supported by the implementers of the policy, both from the school, the education office and parents of students. The contents of the policy must have strengths, interests, and strategies. In policy, it is important to pay attention to the strengths and powers, interests and strategies used by the actors involved to facilitate the implementation of a policy. The contents of the policy have considered the positive and negative impacts on the targets to be achieved.

\section{Interaksi}

The implementation of the education zone policy in Makassar City has been going on for two years. The implementation of the zoning system requires prospective students to take education in schools that have the closest radius of their respective domicile, as in Permendikbud No. 51/2018 concerning the acceptance of new students in the 2019/2020 school year. The selection of prospective students is done by prioritizing the distance of the closest place of residence to school in the zoning determined. The distance of the nearest residence is calculated based on the distance from the village office to the school. If the distance remains the same, then the priority is prospective students who register early. The PPDB zoning selection system is carried out by ranking the zoning route by distance, UN scores, age of students and time of registration.

Educational zoning policy is a kind of policy that is made and implemented in human interaction, open as a machine or system. More emphasis on the nature of the interaction. In the Lipsky model, implementation is something that involves the recognition that organizations contain human and organizational limitations, and that people and organizations are considered as resources. Effective implementation is a condition that can be built from the knowledge and experience of people who are at the forefront of service providers

\section{CONCLUSION}

Based on the results of the study, the implementation of e-government in the service of the Makassar city education zone has not been going well if viewed from communication, resources owned, disposition or behavior and interactions. This happens because due to the lack of standardization of the quality of teachers and infrastructure, so improvements and standardization are needed in improving the quality of education

\section{REFERENCES}

Andina, E. (2017). Sistem Zonasi dan Dampak Psikososial Bagi Peserta Didik. Pusat Penelitian Badan Keahlian DPR RI.

Basu, S. (2004). E-government and developing countries: an overview. International Review of Law, Computers \& Technology. https://doi.org/10.1080/13600860410001674779

Farlina, Y., \& Ikhwani, Y. (2017). Kajian Kepuasan Pengguna Informasi Penerimaan Peserta Didik Baru (PPDB) Online. IJCIT (Indonesian Journal on Computer and Information 
158 Jurnal Administrare: Jurnal Pemikiran Ilmiah dan Pendidikan Administrasi Perkantoran Volume 6 Number 2 July- December 2019. Pages 153-158

Technology).

Grindle, M. (2010). Good Governance: The Inflation of an Idea Faculty Research Working Paper Series. In Harvard University, Center for International Development.

Hardjaloka, L. (2014). Studi Penerapan E-Government Di Indonesia Dan Negara Lainnya Sebagai Solusi Pemberantasan Korupsi Di Sektor Publik. Jurnal Rechts Vinding: Media Pembinaan Hukum Nasional.

Horsburgh, S., Goldfinch, S., \& Gauld, R. (2011). Is public trust in Government associated with trust in E-Government? Social Science Computer Review. https://doi.org/10.1177/0894439310368130

Mashudi, A. (2019). Kebijakan PPDB Sistem Zonasi SMA/SMK dalam mendorong Pemerataan Kualitas Sumberdaya Manusia di Jawa Timur. Nidhomul Haq: Jurnal Manajemen Pendidikan Islam. https://doi.org/10.31538/NDH.V4I2.327

Ningtyas, D. A., Badrul, M., \& Sulistyowati, D. N. (2018). Sistem Informasi Penerimaan Peserta Didik Baru Pada Smp Ar-Ridha Jakarta. Techno Nusa Mandiri.

Pangaribun, E. N. (2018). Sistem Zonasi. antaranews. Diambil dari antaranews.com

Peraturan Menteri Pendidikan dan Kebudayaan No. 17 Tahun 2017. Peraturan Menteri Pendidikan dan Kebudayaan No. 17 Tahun 2017. , (2017).

Pressman, J. L., \& Wildavsky, A. B. (1973). Implementation: how great expectations in Washington are dashed in Oakland. The Oakland Project Series.

Purwanti, D., Irawati, I., \& Adiwisastra, J. (2018). Efektivitas Kebijakan Penerimaan Peserta Didik Baru Sistem Zonasi Bagi Siswa Rawan Melanjutkan Pendidikan. Dinamika.

Rahmawati, aullia, \& Muflhatin, M. (2019). Komunikasi dalam Implementasi Kebijakan Penerimaan Peserta Didik Baru(PPDB) Zonasi di Sekolah Menengah Pertama (SMP) Kabupaten Kediri. Jurnal Dinamika Manajemen Pendidikan. https://doi.org/10.2674/JDMP.V3N1.P56-61

Silcock, R. (2001). What is e-Government? Parliamentary Affairs. https://doi.org/10.1093/pa/54.1.88

Sosiawan, E. A. (2008). Tantangan Dan Hambatan Dalam Implementasi E-Government Di Indonesia. Seminar Nasional Informatika.

Wulandari, D., Hasyim, A., \& Nurmalisa, Y. (2018). Pengaruh Penerimaan Peserta Didik Baru Melalui Sistem Zonasi Terhadap Prestasi Belajar Siswa. Jurnal Kultur Demokrasi. 